\title{
Referaten
}

\section{Compassie, empathie en empathisch gedrag; belangrijke dimensies van het artsenvak}

Shapiro J. How do physicians teach empathy in the primary care setting? Acad Med 2002;77:323-8.

Mangione S, Kane GC, Caruso JW, Gonnella JS, Nasca TJ, Hojat M. Assessment of empathy in different years of internal medicine training. Med Teach 2002;24(4):370-3.

McGaghie WC, Mytko JJ, Brown WN, Cameron $J R$. Altruism and compassion in the health professions: a search for clarity and precision. Med Teach 2002;24(4):374-8.

Recentelijk was er in de praktijk van één van ons een student die een tweede poging deed de stage huisartsgeneeskunde tot een goed einde te brengen. Tijdens de vorige stage was niet mogelijk gebleken deze student goed te kunnen beoordelen. De student had bovendien niet genoeg vorderingen getoond. Hij was niet voldoende betrokken en het algemeen besluit was dat zijn attitude tekort was geschoten, zeker wat betreft typisch huisartsgeneeskundige aspecten. Tijdens het intakegesprek met de student bleek dat zich een aantal problemen had voorgedaan tijdens de vorige stage. De student zat met veel existentiële vragen: 'wil ik wel arts worden?', 'hoeveel van mezelf wil ik er in stoppen?', 'hoeveel wil ik met mensen meevoelen?', 'tot waar wil ik met die patiënten meevoelen?' en 'waar gaat mijn meevoelen te ver?'. De ervaringen tot dan toe hadden hem aan het twijfelen gebracht, en dat verklaarde zijn onmacht om te leren en te groeien in de vorige huisartsenstage.

Met de student werd bij aanvang van de stage afgesproken dat hij zich zou focussen op twee belangrijke aspecten. Ten eerste zou de inhoud van het huisartsenvak actief onderzocht worden en ten tweede de plaats die de student in de medische wereld zou willen gaan innemen. In de eerste week van de stage bleek de student in staat een aantal vorderingen te maken. Hij speelde gretig in op allerlei patiëntencasus, hij analyseerde de problemen aan de hand van richtlijnen, hij vond op internet de meest up-todate evidence-based informatie en hij oefende vaardigheden. Hij bleek dus één van de belangrijke aspecten van deze stage goed in te vullen.

Hoe het zat met een ander deel van zijn attitude, namelijk zijn functioneren als arts bleek pas later, toen een echte patiënt voor hem op het spreekuur kwam. Een man die later dood zou gaan. Vanaf de derde dag tot twee weken later was de student bij deze patiënt betrokken. Zelfs op het moment van de dood, waar hij bij aanwezig was. Het was wat je zou kunnen noemen een volkomen fysiologische manier van sterven. Na een eerste huivering de relatie met deze man en zijn echtgenote aan te gaan, bleek de student toch aangesproken op zijn rol als arts-hulpverlener. Hij had voor het eerst iemand zien sterven en het was een hele ervaring. Het dilemma 'tot hoever gaat mijn empathie?', één van de moeilijke aspecten van zijn vorige mislukte stage, heeft deze student tenminste éénmaal aan den lijve gevoeld. Ook de patiënt en zijn omgeving waren tevreden. Al met al groeide de student tijdens de stage. Er was echter aan het einde van de stage een substantieel verschil in appreciatie van de student door beoordelaar 1 en beoordelaar 2 . Naar aanleiding hiervan, en op grond van bevindingen in de literatuur, zou men zich de vraag kunnen stellen of het mogelijk is op een verantwoorde manier een uitspraak te doen over de groei bij een student.

Het is bekend dat clinici over het algemeen wel een idee hebben over het belang van empathie, maar dat ze nogal verschillen over de precieze inhoud ervan (Shapiro). Sommigen vinden het een aparte vaardigheid, terwijl anderen het juist een algemeen attitudekenmerk vinden. Het verfijnen ervan zou juist afbreuk doen aan het belang ervan als eigenschap voor elke dokter. In ieder geval kan gesteld worden dat er gedragsmatige- en attitudekenmerken bij betrokken zijn.

Het is moeilijk de menselijke aspecten van het medisch beroep te meten. In dat licht is het leuk te zien dat in de juli 2002 uitgave van Medical Teacher twee bijdragen hierover werden 
opgenomen. In een eerste doen Mangione et al. verslag van een studie, waarin een gevalideerd instrument (de Jefferson Scale of Phycisian Empathy, 20 items) bij internisten-in-opleiding werd gecorreleerd met de meningen van opleidingscoördinatoren. Het bleek dat er geen significante verschillen waren tussen de scores van verschillende jaargroepen. Bovendien was de correlatie van de score met de meningen van de opleidingscoördinatoren laag $(r=0.17)$. De conclusie van de studie van Mangione et al. is dat empathie misschien een redelijk stabiele eigenschap is.

McGaghie et al. doen in hetzelfde nummer van Medical Teacher een poging om het begrip compassie te operationaliseren. Docenten geven vaak aan dat de 'goede' arts voldoende empathie moet tonen en dat het tonen van deze eigenschap een positief effect heeft op de tevredenheid van patiënten. De 'aardige' dokter doet het immers altijd beter. Anderzijds is het gedrag dat studenten tegenkomen tijdens de opleiding niet altijd conform dit ideaal. In de universiteiten en klinische opleidingsplaatsen wordt empathie nogal eens afgestraft en redelijk onbelangrijk gevonden. Al met al, zo besluiten de auteurs het eerste deel van hun betoog, een verwarrende situatie voor studenten.

McGaghie et al. ontwikkellen vervolgens een model waarin aangegeven wordt hoe empathie ontstaat en hoe je het kunt beïnvloeden. Dit model hanteert enkele uitgangspunten. Belangrijk zijn de begrippen compassie en altruïstisch gedrag. Van belang is dat vanuit de persoonlijkheid het gedrag wordt aangestuurd. Hieruit wordt het gedrag zichtbaar in de vele situaties die je als arts dagelijks tegenkomt. Het gedrag wordt in de loop van de tijd geplooid door de ervaringen die men opdoet. Zoals alle gedrag zijn er negatieve en positieve stimuli. De auteur komt op theoretische gronden tot vijf assumpties.

- Compassie is de basis, en is in de persoonlijkheid aanwezig. Altruïstisch gedrag (empathisch gedrag is een betere vertaling, zie verder) is het observeerbare gedrag van compassie.

- Positieve bevestiging van altruïstisch (empathisch) gedrag verhoogt de kans op toekomstig altruïstisch gedrag en versterkt de kern van compassie in de persoonlijkheid.

- Altruïstisch gedrag (empathisch gedrag) is afhankelijk van de situatie; sommige situaties nodigen uit, andere remmen juist dit gedrag af.

- Altruïstisch (empathisch) gedrag wijst op consistentie. Ook wanneer de situaties wisselen is er een grotere kans op altruïstisch gedrag.
- Altruïstisch (empathisch) gedrag wordt getoond als de kostprijs voor de persoon, bewust of onbewust, ondergeschikt is gemaakt aan dit gedrag.

Een bedenking bij dit model is van taalkundige aard. Altruïsme is het woord dat de (Amerikaanse) auteurs gebruiken. Dit zou in het Nederlands taalgebied een negatieve bijklank kunnen hebben. Zo zou men een verband kunnen veronderstellen met altruïsme en het overnemen van allerlei verantwoordelijkheden die toch beter bij de patiënt of andere hulpverleners blijven. Dan ligt burn-out van artsen op de loer, zoals we de laatste jaren leren in met name huisartsenkringen. Teveel ervan is dus niet goed, en dat voelde onze student ook op zich afkomen. Misschien volstaat het in ons taalgebied om het begrip empathie als karaktertrek en als uiting ervan in de hulpverlening te hanteren. Empathisch gedrag is dan een betere vertaling naar onze cultuur en taalgebied, alhoewel ze misschien toch een zekere overlap blijven vertonen.

Ons komt het voor dat compassie, empathie en empathisch gedrag deels overlappende eigenschappen zijn die als het ware in een glijdende schaal in elkaar overgaan. Zij zijn allen van wezenlijk belang voor een arts. Een medicus zonder voldoende bagage op dit terrein is misschien een gevaar voor zijn patiënten. Misschien moet zo iemand maar beter geen arts worden. Het instrument van Mangione en het model van McGaghie laten in de toekomst misschien toe empathie, compassie en empathisch gedrag als werkbaar concept te gebruiken in het medisch onderwijs.

In communicatietrainingen kan men in het basis- en vervolgonderwijs deze eigenschappen bespreekbaar maken en misschien zelfs oefenen met studenten. Ook is het belangrijk, met of zonder verdere conceptvorming, dat klinische docenten op de stageplaatsen, dus daar waar echte patiëntenzorg wordt geboden, nagaan in welke mate zij empathie en compassie belangrijk vinden en in hoeverre wij dergelijk gedrag bij studenten en specialisten in opleiding positief bevestigen. Als volgende stap is misschien de tijd daar om ook in ons taalgebeid onderzoek naar empathisch gedrag van studenten te gaan doen. Geen onderzoek zonder een goede theorie, wordt soms gezegd. Welnu, blijkbaar hebben we nu wat meer vat op de onderliggende concepten.

Roy Remmen, Antwerpen

Gerard Spaai, Amsterdam 